ROCZNIKI NAUK PRAWNYCH

Tom LXXXI, numer 4 - 2021, s. 55-70

DOI: http://doi.org/10.18290/rnp21314-4

\title{
LUCJAN ŚWITO
}

Uniwersytet Warmińsko-Mazurski

lucjan.swito@uwm.edu.pl

ORCID: https://orcid.org/0000-0002-6392-4599

\section{TOŻSAMOŚĆ RELIGIJNA DZIECKA W PIECZY ZASTĘPCZEJ}

\section{CHILD'S RELIGIOUS IDENTITY IN FOSTER CARE}

\begin{abstract}
Taking into account the religious aspect in child-rearing is not exclusive to parental education, neither are only children growing up in their natural family environments entitled to the right to preserve their religious identity. Also children in foster care are equally entitled to it. Is, however, the right actually respected in Poland? Can, for example, two thirteen-year-old Muslims from Turkey, who are detained at the Central Station in Warsaw after having crossed the border illegally, request placement in a foster family or institution in which they are not required to eat pork, where they can fast in the month of Ramadan and study the Quran? Can Catholic parents, who have been deprived of parental custody, demand that their four-year-old child, who is placed in a family-type children's home run by a religiously indifferent couple, attend weekly Mass and get acquainted with the Bible? This article attempts to address the above-mentioned questions.
\end{abstract}

Keywords: religion; child; foster care; parental authority.

\section{WPROWADZENIE}

Prawo do zachowania tożsamości religijnej ${ }^{1}$, podobnie jak i wolność sumienia i wyznania (religii), należą do fundamentalnych praw człowieka, chronionych

\footnotetext{
${ }^{1}$ Pojęcie tożsamości religijnej zostało wprowadzone na grunt nauk socjologicznych i psychologicznych na początku XX wieku, stając się przedmiotem wielorakich ujęć i koncepcji, zob. M. Libiszowska-ŻóŁtкowska, Prolegomena, [w:] Tożsamości religijne w społeczeństwie polskim. Socjologiczne studium przypadków, red. M. Libiszowska-Żółtkowska, Warszawa: Difin 2009, s. 15. Dla przykładu wskazać należy, że według A. Harbatskiego tożsamość religijna jest to forma grupowej i osobistej świadomości, zbudowanej na uświadomieniu swojej przynależności do określonej religii i kształtująca wyobrażenie o sobie i świecie za pośrednictwem odpowiednich dogmatów religijnych. Zob. A. HARBATSKI, Tożsamość religijna a bezpieczeństwo konfesyjne: wspótczesne wyzwania (na przyktadzie Republiki Białorusi), „Pogranicze. Studia Społeczne” 2015, nr 25, s. 136. Z kolei J. Gunn, pisząc o religii w wymiarze tożsamości, podkreśla szczególną rolę przy-
} 
w krajowym i międzynarodowym porządku prawnym. Wymienione prawa przysługują bez względu na wiek, a więc przysługują nie tylko osobom dorosłym, ale również dzieciom. Abstrahując od polemik co do stopnia dojrzałości, w jakiej dziecko winno uzyskiwać prawo do autonomii w zakresie wyboru wyznawanego systemu wartości i światopoglądu ${ }^{2}$, nie ulega wątpliwości, że akty prawa o charakterze uniwersalnym pierwszorzędną rolę $\mathrm{w}$ pełnieniu funkcji wychowawców dziecka, w tym prawo do wychowania i nauczania dziecka zgodnie $\mathrm{z}$ własnymi przekonaniami religijnymi i filozoficznymi, gwarantują rodzicom ${ }^{3}$. Art. 26 ust. 3 Powszechnej Deklaracji Praw Człowieka z 10 grudnia 1948 r. wprost określa, że rodzice mają prawo wyboru rodzaju nauczania dla swoich dzieci, a art. 18 ust. 4 Międzynarodowego Paktu Praw Obywatelskich i Politycznych z 19 grudnia 1966 r. ${ }^{4}$ oraz art. 13 ust. 3 Międzynarodowego Paktu Praw Gospodarczych i Kulturalnych z 19 grudnia $1966 \mathrm{r}^{5}$ jednoznacznie zobowiązują państwa-strony do zapewnienia rodzicom prawa do wychowania religijnego i moralnego dziecka zgodnie z ich przekonaniami, podobnie jak i art. 2 Protokołu nr 1 do Europejskiej Konwencji o Ochronie Praw Człowieka i Podstawowych Wolności z 4 listopada 1950 r. $^{6}$, który expressis verbis uznaje prawo rodziców do zapewnienia wychowania i nauczania dziecka zgodnie $\mathrm{z}$ własnymi przekonaniami religijnymi i filo-

należności osoby do grupy religijnej zaznaczając, że w owej tożsamości mniej chodzi o podzielanie teologicznych doktryn, ile o pewien wymiar historii, kultury, etniczności i tradycji. Zob. J. GuNN, The Complexity of Religion and the Definition of "Religion” in International Law, „Harward Human Rights Journal” 2003, nr 16, s. 201. H. Mielicka zwraca natomiast uwagę, że tożsamość religijna funkcjonuje jako jeden z wielu schematów percepcyjnych, którymi posługuje się jednostka, zawierający w swojej indywidualno-społecznej strukturze komponent emocjonalny, kognitywny i behawioralny. Zob. H. MielickA, Tożsamość indywidualna a tożsamość spoteczna jako wymiar religijności, [w:] Tożsamości religijne, s. 20. Szerzej na temat tożsamości dziecka pozostającego w pieczy zastępczej zob. M. Burtowy, J. ZajączKowsKa-Burtowy, Tożsamość dziecka w pieczy zastepczej. Po 30 latach od uchwalenia Konwencji o prawach dziecka, „Prokuratura i Prawo” 2020, nr 1, s. 101-115.

${ }^{2}$ Zob. szerzej: K. WARChA£OWSKI, Władza rodzicielska a wolność religijna dziecka $w$ prawie polskim, „Annales Canonici Monographiae” 2015, nr 3, s. 199-214; A. JAKUSZEwICZ, Prawo rodziców do wychowania dzieci zgodnie z własnymi przekonaniami a wolność sumienia $i$ religii dzieci w Konstytucji RP oraz w Konwencji o Prawach Dziecka, „Studia z Zakresu Prawa, Administracji, Zarządzania UKW" 2013, nr 3, s. 115-135. M. PietrZak, Prawo wyznaniowe, Warszawa: LexisNexis 2010; J. Krukowski, Polskie prawo wyznaniowe, Warszawa: LexisNexis 2005.

${ }^{3}$ Paweł Sarnecki zwraca uwagę, że Konstytucja RP przewiduje jedynie ,,prawo” rodziców do wychowania, nie nakłada natomiast obowiązku wychowawczego, tak jak ma to miejsce m.in. w Konstytucji Niemiec, Włoch czy Estonii. Zob. P. SARnecki, Uwagi do artykułu 48 Konstytucji, [w:] Konstytucja Rzeczypospolitej Polskiej. Komentarz, t. 3, red. L. Garlicki, Warszawa: Wydawnictwo Sejmowe 2003, s. 46.

${ }^{4}$ Dz.U. 1977, nr 38, poz. 167.

${ }^{5}$ Dz.U. 1977, nr 38, poz. 169.

${ }^{6}$ Dz.U. z 1993 r., nr 61, poz. 284. 
zoficznymi. Należy nadmienić, że Rzeczpospolita Polska, ratyfikując Konwencję o Prawach Dziecka z 20 listopada 1989 r. ${ }^{7}$, złożyła deklarację, w której wyraziła stanowisko, iż uważa, że wykonywanie przez dziecko między innymi prawa do wolności myśli, sumienia i religii „dokonuje się z poszanowaniem władzy rodzicielskiej, zgodnie z polskimi zwyczajami i tradycjami dotyczącymi miejsca dziecka w rodzinie i poza rodziną"8.

Również ustawodawca polski w art. 48 ust. 1 oraz w art. $53 \mathrm{w}$ zw. z art. 72 ust. 1-3 Konstytucji z 1997 r. zagwarantował rodzicom prawo do wychowania dziecka zgodnie $\mathrm{z}$ własnymi przekonaniami, przede wszystkim w sferze wychowania, religii i światopoglądu, z zastrzeżeniem, że działania wychowawcze mają respektować podmiotowość dziecka i jego prawa, w szczególności wolność sumienia, wyznania i przekonań ${ }^{9}$. Na prawo rodziców do religijnego wychowania dziecka wskazuje również art. 12 pkt 1 Konkordatu ${ }^{10}$, a także szereg innych obowiązujących w Polsce aktów prawnych, między innymi art. 12 ust. 1 ustawy z dnia 7 września 1991 r. o systemie oświaty ${ }^{11}$ (który stanowi, iż publiczne przedszkola, szkoły podstawowe i gimnazja organizują naukę religii na życzenie rodziców), art. 2 pkt 4 ustawy z dnia 17 maja 1989 r. o gwarancjach wolności sumienia i wyznania ${ }^{12}$ (w myśl którego obywatele mogą wychowywać dzieci zgodnie ze swoimi przekonaniami w sprawach religii) czy art. 18 ust. 1 ustawy z dnia 17 maja 1989 r. o stosunku Państwa do Kościoła Katolickiego w Polsce ${ }^{13}$ (zgodnie z którym państwo uznaje prawo Kościoła do nauczania religii oraz religijnego wychowania dzieci i młodzieży, zgodnie z wyborem dokonanym przez rodziców). Na marginesie należy zauważyć, iż zgodnie z art. 32 ustawy z dnia 21 kwietnia 1936 r. o stosunku państwa do Muzułmańskiego Związku Religijnego ${ }^{14}$ nauka religii dla młodzieży wyznania muzułmańskiego w ,zakładach naukowych, których program obejmuje kształcenie młodzieży poniżej lat 18, utrzymywanych w całości lub w części przez Państwo lub ciała samorządowe”, jest obowiązkowa.

${ }^{7}$ Dz.U. z 1989 r., nr 120, poz. 528.

${ }^{8}$ A. N. Schulz, Zastrzeżenia, deklaracje, sprzeciwy do Konwencji o Prawach Dziecka, [w:] Konwencja o Prawach Dziecka. Analiza i wykładnia, red. T. Smyczyński, Poznań: Ars Boni et Aequi 1999, s. 117.

${ }^{9}$ H. BABIUCH, Konstytucyjne prawa rodziców w zakresie wychowania dziecka, [w:] Realizacja i ochrona konstytucyjnych wolności i praw jednostki w polskim porządku prawnym, red. M. Jabłoński, Wrocław 2014, s. 180; M. Ożóg, Prawo rodziców do wychowania dziecka zgodnie z własnymi przekonaniami w świetle Konstytucji Rzeczypospolitej Polskiej z dnia 2 kwietnia 1997 r., „Studia z Prawa Wyznaniowego" 2015, nr 18, s. 263-264.

${ }^{10}$ Dz.U. z 1998, nr 51, poz. 318.

${ }^{11}$ Dz.U. z 1991, nr 95, poz. 425 z późń. zm.

${ }^{12}$ Dz.U. z 1989, nr 29, poz. 155 z późń. zm.

${ }^{13}$ Dz.U. z 1989, nr 29, poz. 154 z późn. zm.

${ }^{14}$ Dz.U. z 1936, nr. 30, poz. 240 z późn. zm. 
Wychowanie uwzględniające aspekt religijny nie jest jednakże domeną wyłącznie wychowania rodzicielskiego, a prawo do zachowania tożsamości religijnej przysługuje nie tylko dzieciom wzrastającym w swych naturalnych środowiskach rodzinnych, lecz przysługuje ono również dzieciom objętym pieczą zastępczą. Art. 5 ust. b Konwencji w sprawie zwalczania dyskryminacji w dziedzinie oświaty z dnia 15 grudnia 1960 r. stanowi, że „rodzice, a w odpowiednich przypadkach prawni opiekunowie powinni mieć możność zapewnienia religijnego i moralnego wychowania dzieci zgodnie z ich osobistymi przekonaniami”, dodaje także, że: „nikomu indywidualnie ani żadnej grupie osób jako całości nie należy narzucać religijnego wychowania niezgodnego z ich przekonaniami”" ${ }^{15}$. Art. 14 ust. 2 Konwencji o Prawach Dziecka w zakresie dotyczącym ukierunkowywania dziecka w korzystaniu z jego praw nakłada na państwa-strony obowiązek respektowania nie tylko praw i obowiązków rodziców, ale w odpowiednich przypadkach również i opiekunów prawnych. Art. 20 ust. 1-3 tego aktu jednoznacznie stanowi, że dziecko pozbawione czasowo lub na stałe swojego środowiska rodzinnego ma nie tylko prawo do specjalnej ochrony i pomocy ze strony państwa, w tym do opieki zastępczej, ale również i prawo do zachowania między innymi swojej tożsamości religijnej.

Norma art. 40 ust. 5 oraz art. 93 ust. 4 pkt 1 ustawy z dnia 9 czerwca 2011 r. o wspieraniu rodziny i pieczy zastępczej ${ }^{16}$ stanowi, że rodzina zastępcza, rodzinny dom dziecka oraz placówka opiekuńczo-wychowawcza winny zapewniać dziecku nie tylko całodobową opiekę, ale również zaspokajać między innymi jego potrzeby religijne. Zgodnie zaś z przywołanym art. 18 ust. 1 ustawy o stosunku Państwa do Kościoła Katolickiego w Polsce decyzje w zakresie religijnego wychowania dzieci i młodzieży podejmować mogą również ich opiekunowie prawni.

Istniejący stan rzeczy skłania zatem do refleksji, jak wygląda relacja między prawami rodziców naturalnych a kompetencjami rodziców zastępczych (czy szerzej: podmiotów sprawujących pieczę zastępczą) w kwestii wychowania religijnego dziecka? Jak w praktyce miałoby wyglądać realizowanie prawa dziecka do zachowania jego tożsamości religijnej w pieczy zastępczej i czy w świetle obowiązujących rozwiązań, prawo to rzeczywiście podlega ochronie? Artykuł stanowi próbę odpowiedzi na te pytania.

${ }^{15}$ Zob. P. KRoczeK, Wychowanie. Optyka prawa polskiego i kanonicznego, Kraków: UPJPII 2013, s. 55.

${ }^{16}$ Dz. U. z 2011 r., nr 149, poz. 887 z późń. zm. (dalej: u.w.r.p.z.). 


\section{PIECZA ZASTĘPCZA - ZARYS ZAGADNIENIA}

Norma art. 48 ust 2 Konstytucji RP z 1997 r. pozwala na ograniczenie lub pozbawienie praw rodzicielskich tylko $\mathrm{w}$ przypadkach określonych $\mathrm{w}$ ustawie i tylko na podstawie prawomocnego orzeczenia sądu. W art. 72 Konstytucji ujęty został obowiązek zapewnienia dziecku ochrony jego praw oraz przewidziane zostało prawo dziecka pozbawionego opieki rodzicielskiej do opieki i pomocy władz publicznych.

Konwencja o Prawach Dziecka w art. 3 ust. 1 za sprawę nadrzędną we wszystkich działaniach dotyczących dzieci uznaje najlepsze zabezpieczenie interesów dziecka, a w art. 9 zobowiązuje państwa-strony do zapewnienia, aby dziecko nie zostało oddzielone od swoich rodziców wbrew ich woli, z wyłączeniem przypadków, w których kompetentne władze, podlegające nadzorowi sądowemu, zdecydują zgodnie z obowiązującym prawem, że takie oddzielenie jest konieczne ze względu na najlepiej pojęte interesy dziecka, szczególnie w przypadkach nadużyć lub zaniedbań ze strony rodziców. Art. 19 Konwencji wskazuje z kolei na konieczność podjęcia wszelkich właściwych środków dla ochrony dzieci przed jakimikolwiek formami przemocy fizycznej bądź psychicznej, krzywdy lub zaniedbania bądź złego traktowania lub wyzysku, zalecając tam, gdzie to właściwe, ingerencję sądu. Natomiast wspomniany art. 20 Konwencji stanowi, że jako odpowiednie formy tej opieki Konwencja wymienia przykładowo umieszczenie w rodzinie zastępczej (w prawie islamskim tzw. kafala ${ }^{17}$ ), adopcję lub - gdy jest to niezbędne - umieszczenie w odpowiedniej instytucji powołanej do opieki nad dziećmi, zalecając przy wyborze odpowiednich rozwiązań uwzględnienie w sposób właściwy konieczności zachowania ciągłości w wychowaniu dziecka oraz jego tożsamości etnicznej, religijnej, kulturowej i językowej.

W doktrynie podkreśla się, że celem pieczy zastępczej jest: „tworzenie możliwości i warunków optymalnego rozwoju dziecka, wspieranie funkcjonowania

\footnotetext{
${ }^{17} \mathrm{~W}$ świecie muzułmańskim adopcja oraz piecza zastępcza rozumiane są w sposób znacząco odmienny niż w tradycji prawa europejskiego. Sam termin ,adopcja” występuje wprawdzie w języ$\mathrm{ku}$ arabskim (tabannin), islam jednak zakazuje adopcji, która miałaby polegać na nawiązaniu stosunku prawnorodzinnego identycznego $\mathrm{z}$ tym, jaki istnieje między biologicznymi rodzicami i dzieckiem. Koran zezwala jednak na istnienie instytucji opiekuńczej w formie kafala. Przyjęcie dziecka do rodziny $\mathrm{w}$ tej formule nie oznacza ustania więzi prawnej pomiędzy nim a jego biologicznymi rodzicami. Kafala nie skutkuje powstaniem stosunku pokrewieństwa między dzieckiem a osobami przyjmującymi dziecko na wychowanie. Zob. szerzej: M. ToMKIEWICZ, Islamska „kafala” a prawo polskie, [w:] Wolność sumienia i religii a bezpieczeństwo i porządek publiczny, red. J. Nikołajew, P. Sobczyk, K. Walczuk, Siedlce: Wydawnictwo Diecezji Siedleckiej UNITAS 2017, s. 149-174; L. Świto, Malżeństwo i rodzina wobec zagrożeń spoleczno-cywilizacyjnych. Kontekst prawny, „Biuletyn Stowarzyszenia Kanonistów Polskich” 2020, nr 33, s. 221-243.
} 
rodziny oraz wyrównywanie dysfunkcji w zachowaniach osób bądź sytuacjach społecznych" ${ }^{\text {} 18}$. Podkreśla się również, iż zasada autonomiczności rodziny oznacza, że ingerencja państwa w stosunki rodzinne jest wyjątkiem, dopuszczalnym najczęściej w sytuacjach patologicznych ${ }^{19}$, gdy zagrożone jest dobro dziecka ${ }^{20}$. Analogiczne stanowisko wyraził Sąd Najwyższy w uchwale z 9 czerwca 1976 r. $^{21}$, stwierdzając, że umieszczenie w pieczy zastępczej ,jest niezbędne, gdy środowisko rodzinne wywiera ujemny wpływ na wychowanie dziecka, albo gdy rodzice nie są $\mathrm{w}$ stanie poradzić sobie $\mathrm{z}$ codziennymi problemami wychowawczymi".

W obecnym systemie prawnym organizacja systemu pieczy zastępczej stanowi zadanie powiatu. $\mathrm{W}$ art. 34 u.w.r.p.z. zostały określone dwie zasadnicze formy wykonywania pieczy: rodzinna i instytucjonalna, które doprecyzowano w art. 39 ust. 1 i art. 93 ust. 1 u.w.r.p.z.

Rodzinna piecza zastępcza wykonywana jest przez rodziny zastępcze spokrewnione, niezawodowe lub zawodowe, przy czym rodziny zastępcze zawodowe mogą pełnić funkcję pogotowia opiekuńczego lub rodziny zawodowej specjalistycznej. Zastępcza piecza rodzinna może też przybrać kształt rodzinnego domu dziecka.

Instytucjonalna piecza zastępcza $\mathrm{z}$ kolei jest sprawowana $\mathrm{w}$ formie placówki opiekuńczo-wychowawczej, regionalnej placówki opiekuńczo-terapeutycznej oraz interwencyjnego ośrodka preadopcyjnego. Sąd umieszcza dziecko w instytucjonalnej pieczy zastępczej, jeżeli brak jest możliwości umieszczenia dziecka w rodzinnej pieczy zastępczej lub z innych ważnych względów nie jest to zasadne. $\mathrm{W}$ regulacji tej została wyrażona zasada preferencji rodzinnych form pieczy zastępczej $^{22}$.

Norma art. 35 ust. 1 u.w.r.p.z. jako regułę przyjmuje, że podstawą umieszczenia dziecka w pieczy zastępczej jest orzeczenie sądu. Wyjątki od tej zasady przewidziano jedynie $\mathrm{w}$ razie pilnej konieczności, na wniosek lub za zgodą

${ }^{18}$ W. HellincKx, Nowe tendencje $w$ opiece nad dzieckiem $w$ Europie, [w:] Zmiany $w$ systemie opieki nad dziećmi i młodzieżą. Perspektywa europejska, red. Z. Stelmaszuk, Katowice: Śląsk 2001, s. 118. M. Baranowska-Bolesta, Legal Guardianship of Minors. Selected Issues, „Studia Iuridica Lublinensia" 2020, nr 1, s. 47-66.

${ }^{19}$ A. SteLmachowsKi, Zarys teorii prawa cywilnego, Warszawa: Wydawnictwo Naukowe PWN 1998, s. 38.

${ }^{20}$ T. SMyczyŃski (red.), System Prawa Prywatnego. Prawo rodzinne i opiekuńcze, t. 11. Warszawa: Wydawnictwo C.H. Beck 2014, s. 3.

${ }^{21}$ OSNC 1976, nr 9, p. 184.

${ }^{22}$ J. WIERCIŃSKI (red.), Kodeks rodzinny i opiekuńczy. Komentarz, Warszawa: LexisNexis 2014, s. 758; H. Dolecki (red.), Kodeks rodzinny i opiekunczy. Komentarz, Warszawa: Wolters Kluwer 2013, s. 790. 
rodziców dziecka $\mathrm{i}$ na podstawie umowy zawartej przez starostę $\mathrm{z}$ rodziną zastępczą lub prowadzącym rodzinny dom dziecka, o czym niezwłocznie zawiadamiany jest sąd. Umowa ma charakter interwencyjny i wygasa $\mathrm{z}$ chwilą zakończenia sądowego postępowania z zakresu pieczy zastępczej (art. 35 ust. 2 u.w.r.p.z.). Objęcie dziecka pieczą zastępczą bez orzeczenia sądu dopuszczono także w wypadkach, w których dziecko zostało doprowadzone przez Policję lub Straż Graniczną do zawodowej rodziny pełniącej funkcję pogotowia rodzinnego lub do placówki opiekuńczo-wychowawczej typu interwencyjnego (art. 58 ust. 1 pkt 2 oraz art. 103 ust. 2 pkt 2 u.w.r.p.z.), a także wtedy, gdy występuje bezpośrednie zagrożenie życia lub zdrowia dziecka $\mathrm{w}$ związku $\mathrm{z}$ przemocą w rodzinie (art. 58 ust. pkt 3 oraz art. 103 ust. 2 pkt 3 u.w.r.p.z. w związku z art. 12a ustawy z dnia 29 lipca 2005 r. o przeciwdziałaniu przemocy w rodzinie ${ }^{23}$ ). Wskazane w art. 35 ust. 1 u.w.r.p.z. wyjątki dotyczą więc sytuacji nagłych, wymagających natychmiastowego zapewnienia tymczasowej opieki i każdorazowo łączą się $\mathrm{z}$ obowiązkiem niezwłocznego ( $\mathrm{w}$ ciągu 24 godzin) powiadomienia sądu o umieszczeniu dziecka w pieczy zastępczej (art. 58 ust. 3 i art. 103 ust. 8 u.w.r.p.z. oraz art. 12a ust. 4 ustawy o przeciwdziałaniu przemocy w rodzinie). Zawiadomienie powoduje wszczęcie $\mathrm{z}$ urzędu postępowania opiekuńczego.

Przepisy ustawy o wspieraniu rodziny i pieczy zastępczej skupiają się na organizacyjnym aspekcie jej sprawowania, natomiast materialno-prawne podstawy umieszczenia dziecka w pieczy zastępczej i doboru właściwej formy pieczy, a także zasady postępowania mające minimalizować negatywne skutki oddzielenia od rodziców, zostały zawarte w art. 100 oraz art. 109-111 Kodeksu rodzinneg i opiekuńczego ${ }^{24}$, dotyczących ingerencji sądowej w sprawowanie władzy rodzicielskiej, oraz w art. $112^{1}$ k.r.o. i następnych regulujących pieczę zastępczą. Sposób sformułowania art. $112^{5}-112^{8}$ k.r.o., zawierających adresowane do sądu konkretne wskazówki dotyczące wyboru właściwych warunków życiowych dziecka, połączone $\mathrm{z}$ przyznaniem sądowi znacznej swobody decyzyjnej w wyborze (art. $112^{5} \S 2$ i art. $112^{7} \S 1$ k.r.o.) jednoznacznie wskazuje, że obowiązkiem sądu jest całościowe, kazuistyczne zbadanie potrzeb dziecka i dopasowanie do nich nie tylko formy pieczy zastępczej, ale także osób, które będą tę pieczę wykonywać.

Sąd może powierzyć sprawowanie pieczy zastępczej małżonkom albo osobie niepozostającej w związku małżeńskim, którzy są wstępnymi albo rodzeństwem dziecka, albo też osobom, które nie są z dzieckiem w tym stopniu spokrewnione, jeżeli zostały wpisane do rejestru osób zakwalifikowanych do pełnienia funkcji

\footnotetext{
${ }^{23}$ Dz.U. z 2005 r., nr 180, poz. 1493 z późn. zm.

${ }^{24}$ Dz.U. 1964, nr 9, poz. 59 (dalej skrót: k.r.o.).
} 
rodziny zastępczej lub taką funkcję pełniących, a także - jeżeli dobro dziecka za tym przemawia - tymczasowo nawet osobom niemogącym się wykazać odpowiednimi kwalifikacjami.

Kandydaci na rodzinę zastępczą (również spokrewnioną) muszą co do zasady spełniać szczegółowe wymagania określone w art. 42 u.w.r.p.z., między innymi: dają rękojmię należytego sprawowania pieczy zastępczej, nie byli i nie są pozbawieni władzy rodzicielskiej (czy też władza rodzicielska nie była im ograniczona ani zawieszona), wypełniają obowiązek alimentacyjny, mają pełną zdolność do czynności prawnych oraz są zdolni do sprawowania właściwej opieki nad dzieckiem, co zostało potwierdzone zaświadczeniem lekarskim o stanie zdrowia oraz opinią o posiadaniu predyspozycji i motywacji do pełnienia funkcji rodziny zastępczej lub prowadzenia rodzinnego domu dziecka wystawioną przez psychologa. Ponadto osoby te muszą zapewnić odpowiednie warunki bytowe i mieszkaniowe, umożliwiające dziecku zaspokajanie jego indywidualnych potrzeb, w tym rozwoju emocjonalnego, fizycznego i społecznego, właściwej edukacji i rozwoju zainteresowań, wypoczynku i organizacji czasu wolnego. W każdym przypadku decyzja co do umieszczenia dziecka w odpowiedniej formule pieczy zastępczej musi być zgodna $\mathrm{z}$ dobrem dziecka - podstawową dyrektywą podejmowania rozstrzygnięć przez sąd opiekuńczy.

Umieszczenie w rodzinie zastępczej może nastąpić również w trybie ustawy z dnia 26 października 1982 r. o postępowaniu w sprawach nieletnich ${ }^{25}$. Zgodnie $\mathrm{z}$ art. 6 ust. 9 tej ustawy sąd rodzinny może - w ramach środka wychowawczego - orzec wobec osoby nieletniej umieszczenie jej w rodzinie zastępczej zawodowej, która ukończyła szkolenie przygotowujące do sprawowania opieki nad nieletnim.

\section{PYTANIA I WĄTPLIWOŚCI}

Zatrzymując się na literalnej treści wskazanych we wstępie przepisów, mających na celu gwarantowanie zachowania tożsamości religijnej dziecka, w tym dziecka pozostającego w pieczy zastępczej, można dojść do przekonania, że materia ta w porządku prawa polskiego jest uregulowana w taki sposób, że w zasadzie wszystko w niej jest jasne. Problem jednak w tym, że przy głębszej analizie pojawiają się pytania, na które trudno odpowiedzieć wprost i jednoznacznie. $\mathrm{Na}$ przykład: czy praktykujący katolicyzm dziadkowie, ustanowieni rodziną zastępczą dla 7-letniego wnuka, który do tej pory był wychowywany w religii anglikańskiej i którego rodzice nie zostali pozbawieni władzy rodzicielskiej, lecz na stałe

\footnotetext{
${ }^{25}$ Dz. U. z 2014 r., poz. 382.
} 
przebywają w Londynie, mogą - w świetle prawa polskiego - posłać wnuka do katolickiej szkoły podstawowej? Czy wychowawcy placówki opiekuńczo-wychowawczej (domu dziecka), w którym przybywa dziewięcioro ochrzczonych dzieci pochodzących z rodzin katolickich, dwoje prawosławnych, czternaścioro dzieci nieustalonego pochodzenia oraz jeden obrzezany chłopiec, mają obowiązek zorganizować dwie wieczerze wigilijne $w$ różnych datach, a także święto Chanuka? Czy dwoje muzułmańskich 13-latków z Turcji, którzy po nielegalnym przekroczeniu granicy zostaną zatrzymani na Dworcu Centralnym w Warszawie, mogą domagać się umieszczenia $\mathrm{w}$ takiej rodzinie zastępczej lub placówce, w której nie je się wieprzowiny, pości w miesiącu ramadan i w której będą mogli pobierać naukę Koranu? Czy katoliccy rodzice, którzy zostali pozbawieni władzy rodzicielskiej, mogą domagać się, aby ich 4-letnie dziecko umieszczone w rodzinnym domu dziecka prowadzonym przez religijnie obojętne małżeństwo uczestniczyło w cotygodniowej Mszy św. oraz aby poznawało Biblię?

Podejmując próbę odpowiedzi na powyższe pytania, należałoby zacząć przede wszystkim od ustalenia kwestii władzy rodzicielskiej i podstawy prawnej umieszczenia dziecka w pieczy zastępczej. W literaturze przedmiotu wyróżnia się trzy sytuacje: 1) gdy dziecko umieszczono w pieczy zastępczej na wniosek rodziców; 2) gdy dziecko przebywa w pieczy zastępczej na podstawie ograniczenia władzy rodzicielskiej lub na podstawie ustawy o postępowaniu w sprawach nieletnich; 3) gdy nad dzieckiem sprawowana jest opieka prawna ${ }^{26}$.

W pierwszym przypadku należy przyjąć, że nie doszło do ingerencji sądu w sferę władzy rodzicielskiej, w związku z czym rodzice nadal zachowują pełnię władzy rodzicielskiej, a to oznacza, że mogą oni w czasie pobytu dziecka poza rodziną $\mathrm{w}$ pełni decydować o jego sprawach, obowiązki zaś, jak prawa podmiotów sprawujących pieczę zastępczą sprowadzają się tylko do wykonywania tzw. pieczy bieżącej. W doktrynie powszechnie przyjmuje się, że piecza bieżąca to piecza faktyczna nad dzieckiem, tzn. troska o dziecko związana z oddziaływaniem na nie w trakcie zwykłych codziennych czynności życiowych (zapewnienie dziecku bezpieczeństwa, opieki lekarskiej, odpowiedniego pożywienia, odzieży, wypoczynku, a także dbałość o wykonywanie przez dziecko obowiązku szkolnego) ${ }^{27}$.

W drugim przypadku, gdy sąd ograniczył rodzicom władzę rodzicielską lub też umieścił dziecko w rodzinie zastępczej na podstawie ustawy o postępowaniu w sprawach nieletnich, w grę wchodzi tzw. piecza podzielona, czyli prerogatywy

${ }^{26}$ J. WieRCIŃSKI (red.), Kodeks rodzinny, s. 169; S. ŁAKOMA, Instytucja rodzin zastępczych w prawie administracyjnym, Łódź: Uniwersytet Łódzki 2014, s. 228.

${ }^{27}$ Tamże. 
władzy rodzicielskiej (prawa i obowiązki wynikające z władzy rodzicielskiej) są rozdzielone pomiędzy rodziców a osoby i instytucje sprawujące pieczę zastępczą. Kwestię tę reguluje art. 112 [1] §1-2 k.r.o., w świetle którego obowiązek i prawo wykonywania bieżącej pieczy nad dzieckiem umieszczonym w pieczy zastępczej, jego wychowania i reprezentowania w tych sprawach, należą do rodziny zastępczej, natomiast pozostałe obowiązki i prawa wynikające $\mathrm{z}$ władzy rodzicielskiej należą do rodziców naturalnych dziecka (o ile sąd opiekuńczy nie postanowił inaczej). Rodzice zachowują zatem co do zasady prawo do decydowania o wszystkich istotnych sprawach dziecka, w tym w sprawach wykraczających poza zakres pojęcia „piecza bieżąca” czy zarząd majątkiem dziecka. W kontekście art. $112^{1} \S 1$ k.r.o. należy zauważyć, że przepis ten, przekazując rodzinom zastępczym i placówkom obowiązek wychowania dziecka, może rodzić wątpliwości co zakresu uprawnień objętych tym terminem. Tego samego określenia „wychowanie” razem z pojęciem „kierowanie” ustawodawca używa bowiem również w art. 96 k.r.o. w odniesieniu do władzy rodzicielskiej. W ślad za M. Andrzejewskim należy jednak zgodzić się z tezą, że jakkolwiek z każdym procesem wychowania łączy się jakiś element kierowania, to jednak Kodeks rodzinny i opiekuńczy posługuje się terminem „wychowanie” w jego znaczeniu potocznym (,całokształt zabiegów mających na celu ukształtowanie człowieka pod względem fizycznym, moralnym i umysłowym oraz przygotowanie do życia w społeczeństwie" ${ }^{28}$ ), a „kierowanie” wymienia odrębnie, nadając mu odmienną treść, na którą składa się - ujmując rzecz w skrócie - decydowanie o istotnych sprawach dziecka. „Owo kierowanie, jako nieprzekazane $w$ art. $112^{1}$ k.r.o. rodzicom zastępczym lub placówce, ustawodawca pozostawił rodzicom naturalnym

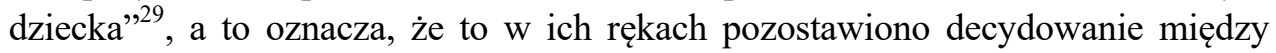
innymi o przynależności dziecka do organizacji czy o jego światopoglądzie ${ }^{30}$.

$\mathrm{W}$ trzeciej z kolei sytuacji, gdy dziecko umieszczono w rodzinie zastępczej na podstawie orzeczenia sądu o pozbawieniu rodziców władzy rodzicielskiej, sąd ustanawia nad dzieckiem opiekę. Opiekunami dziecka w rodzinie zastępczej są przede wszystkim rodzice zastępczy (art. $149 \S 4$ pkt 1 k.r.o.). W myśl art. 155 $\S 2$ k.r.o. do sprawowania opieki stosuje się odpowiednio przepisy o władzy rodzicielskiej z zachowaniem podanych dalej przepisów.

\footnotetext{
${ }^{28}$ M. AndRZejewski, Pojęcie pieczy zastępczej, [w:] System Prawa Prywatnego. Prawo rodzinne i opiekuńcze, red. T. Smyczyński, t. 12, Warszawa: Wydawnictwo C.H. Beck 2011, s. 437; TENżE, Sytuacja prawna wychowanka pieczy zastępczej, [w:] TENŻE, Status prawny osoby małoletniej (piecza zstępcza, kontakty, przysposobienie), Warszawa: INP PAN 2020.

${ }^{29}$ Tamże.

${ }^{30}$ Tamże.
} 
Z powyższego wynikałoby zatem, że jedynie $\mathrm{w}$ trzeciej $\mathrm{z}$ opisanych sytuacji rodzice naturalni, tracąc prerogatywy związane $\mathrm{z}$ władzą rodzicielską, tracą również wpływ na kwestie związane $\mathrm{z}$ religijnym wychowania dziecka. W obu wcześniejszych przypadkach ich stanowisko w omawianej materii nadal ma charakter wiążący. Oznacza to, że np. wyznający katolicyzm dziadkowie, ustanowieni rodziną zastępczą dla swego kilkuletniego wnuka, nie mogą ochrzcić dziecka w Kościele katolickim, jeśli posiadająca władzę rodzicielską matka dziecka, będąca członkiem Kościoła Chrześcijan Baptystów, nie wyraża na to zgody $^{31}$.

Taki kierunek interpretacyjny można dostrzec również w orzecznictwie Europejskiego Trybunału Praw Człowieka. W wyroku z 22 czerwca 1989 r. w sprawie Eriksson v. Sweden ${ }^{32}$ Trybunał orzekł, że rodzice oraz prawni opiekunowie mogą stracić prawo gwarantowane $\mathrm{w}$ art. 2 I Protokołu, jeżeli zostaną pozbawieni praw rodzicielskich $\mathrm{w}$ wyniku orzeczenia sądu czy rozwiązania adopcji. Natomiast w wyroku z 24 marca 1988 r. w sprawie Olsson v. Sweden ${ }^{33}$ Trybunał uznał, że w przypadku, gdy prawa rodzicielskie zostaną jedynie ograniczone, np. na skutek choroby, przekazanie dziecka do rodziny zastępczej bądź „oddanie na wychowanie do zakładu opieki społecznej" nie stwarza sytuacji, w której dzieci nie miałyby być wychowywane zgodnie z przekonaniami czy w religii, jaką wyznają rodzice.

Ustalenie wskazanej kwestii $\mathrm{w}$ pewnej mierze porządkuje zagadnienie na płaszczyźnie normatywnej, niewątpliwie nie wyjaśnia jednak analizowanego problemu w całej jego złożoności. Pozbawienie rodziców władzy rodzicielskiej, a tym samym i prawa do wychowywania dziecka w wyznawanej przez siebie religii nie oznacza wszak, że z ustaniem władzy rodzicielskiej automatycznie ustaje także prawo dziecka do zachowania swojej tożsamości religijnej. Prawo dziecka do wychowania w „religii ojców” jest niejako prawem samym w sobie i podlega ochronie nie tylko ze względu na wychowawcze prawa rodziców. Zachowanie tożsamości religijnej podlega ochronie również (a raczej przede wszystkim) jako prawo osobiste samego dziecka, aczkolwiek nie ulega wątpliwości, że tożsamość ta nie determinuje światopoglądu raz na zawsze. Prawo do zmiany religii lub odstąpienia od dotychczasowych wierzeń i przekonań jest

\footnotetext{
${ }^{31} \mathrm{Na}$ marginesie należy zauważyć, że również Kościół katolicki wymaga zgody rodziców lub przynajmniej jednego z nich albo „tych, którzy ich prawnie zastępują” do godziwego ochrzczenia dziecka (kan. $868 \S 1$ KPK). Jedynie „dziecko rodziców katolickich, a nawet i niekatolickich, znajdujące się w niebezpieczeństwie śmierci, jest godziwie chrzczone, nawet wbrew woli rodziców" (kan. 868 § 2 KPK). Szerzej zob. P. KRoczeK, Sytuacja prawna dzieci w kontekście Chrztu świętego $i$ wychowania religijnego, „Studia Oecumenica” 2013, nr 13, s. 161-174.

${ }^{32}$ Judgment Eriksson v. Sweden, 22 June 1989, application n. 11373/85.

${ }^{33}$ Judgment Olsson v. Sweden, 24 March 1988, application n. 10465/83.
} 
jednym z atrybutów wolności sumienia i wyznania, tyle że - co należy podkreślić - pojawia się wraz ze zdolnością do świadomego rozeznania. Dziecko poddane pieczy zastępczej ma prawo, wraz z rozwojem stopnia dojrzałości, do własnych wyborów i decyzji w kwestii światopoglądowych, do czasu jednak, gdy ten stan osiągnie, ma prawo, aby jego tożsamość religijna, wyniesiona $\mathrm{z}$ rodziny generacyjnej, była w owej pieczy zastępczej chroniona. Jak tego dokonać, gdy opiekunowie prawni lub osoby sprawujące pieczę bieżącą są wyznawcami innej religii lub nie wyznają żadnej? Odpowiedź na to pytanie jest trudna. Przede wszystkim dlatego, że na próżno szukać odpowiedzi na nie w obowiązujących regulacjach prawnych, a i odwołanie się do praktyki, judykatury i doktryny jest tu mało pomocne.

W odniesieniu do przepisów prawa należy zauważyć, że ustawa o wspieraniu rodziny i pieczy zastępczej poza lakonicznym stwierdzeniem zawartym w przywołanym art. 40 ust. 5 oraz art. 93 ust. 4, że podmioty sprawujące pieczę zastępczą są obowiązane zaspokajać potrzeby religijne dziecka, kwestii tej bliżej nie precyzuje. Jak tymczasem miałoby wyglądać zaspokajanie „potrzeb religijnych” np. dziecka 2-letniego, które takich potrzeb ani sobie nie uświadamia, ani ich nie zwerbalizuje, trudno dociec. Znamienne w tym kontekście jest i to, że również rozporządzenie Ministra Pracy i Polityki Społecznej z 22 grudnia 2011 r. w sprawie instytucjonalnej pieczy zastępczej ${ }^{34}$, mimo że bardzo szczegółowo, a nawet wręcz drobiazgowo precyzuje np. to, ile razy pracownik sprawujący opiekę w godzinach nocnych winien przeprowadzić obchód ( $\$ 12$ ust. 2), do tematu zaspokajania potrzeb religijnych dzieci przebywających w tego rodzaju placówkach nie odnosi się wcale, pomijając je całkowicie milczeniem. Kwestie związane $\mathrm{z}$ przynależnością religijną dziecka nie są expressis verbis ujmowane ani $\mathrm{w}$ wymogach dotyczących planu pomocy dziecku, ani też w karcie pobytu dziecka. Jedyną wzmianką, jaka w tym rozporządzeniu nawiązuje do aspektu religijnego, jest przepis mówiący o tym, że dziecku umieszczonemu w placówce opiekuńczo-wychowawczej albo w regionalnej placówce opiekuńczo-terapeutycznej zapewnia się wyżywienie dostosowane do jego potrzeb, między innymi religijnych (§ 18 ust. 1 pkt 1). Rozporządzenie to nie określa jednak, chociażby w ogólnym zarysie, jak miałoby wyglądać organizowanie praktyk religijnych dzieci przebywających $\mathrm{w}$ tych placówkach i do czego jest $\mathrm{w}$ tej materii zobowiązany (a do czego nie) pracujący tam personel.

Niezależnie od powyższego pewne wątpliwości może budzić również sam zakres przedmiotowy owej ochrony tożsamości. Z literalnego brzmienia wspomnianego art. 20 Konwencji o Prawach Dziecka w sposób dość wyraźny wynika,

\footnotetext{
${ }^{34}$ Dz. U. Nr 292, poz. 1720.
} 
że ochronie, o której w tym przepisie mowa, podlega jedynie zachowanie tożsamości religijnej dziecka. Również ustawa o wspieraniu rodziny i pieczy zastępczej wśród potrzeb, które zgodnie z przepisami mają być zaspokajana, wyraźnie wymienia potrzeby religijne. Oznaczałoby to a contrario, że w przypadku, gdy dziecko nie ma tożsamości religijnej, lecz niefideistyczną (np. pochodzi z rodziny o wyraźnym światopoglądzie ateistycznym), to jego tożsamość takiej ochronie już nie podlega. Tezę tę pośrednio wywieść można również ze stanowiska judykatury, zgodnie z którym określona w art. 53 ust. 1 Konstytucji RP wolność religii nie obejmuje światopoglądu niereligijnego ${ }^{35}$. Jeśli więc wyznający światopogląd areligijny rodzice dziecka umieszczonego w pieczy zastępczej zostaną pozbawieni władzy rodzicielskiej, nie ma żadnych formalnych podstaw, które nakazywałyby respektowanie tego światopoglądu w procesie wychowawczym dziecka.

\section{WNIOSKI}

Problematyka ochrony tożsamości religijnej dziecka w pieczy zastępczej nie była jak dotąd przedmiotem większego zainteresowania doktryny $\mathrm{i}$ - jak pokazuje praktyka orzecznicza - nie jest też przedmiotem pogłębionej refleksji sądów. W przypadku gdy dziecko trafia do rodziny zastępczej spokrewnionej, a więc do środowiska, które z założenia prezentuje, jeśli nie ten sam, to przynajmniej zbliżony system wartości, zagadnienie owej ochrony tożsamości co do zasady nie budzi większych zastrzeżeń, choć i w takich przypadkach zdarzają się wyjątki. Zasadnicze problemy pojawiają się jednak wówczas, gdy dziecko zostaje umieszczone w innej formule niż spokrewniona rodzina zastępcza, a zwłaszcza gdy trafia do placówki opiekuńczo-wychowawczej.

Obowiązujące w Polsce przepisy prawne zdają się wskazywać, że troska o ochronę tożsamości religijnej dziecka w pieczy zastępczej nie jest obca ustawodawcy polskiemu. Rzecz jednak w tym, że o ile owa ochrona tożsamości religijnej jest gwarantowana na poziomie normatywnym, o tyle w praktyce jest ona w znacznej mierze iluzoryczna. Taki stan rzeczy jest wypadkową kilku okoliczności. Po pierwsze, składa się na to brak bliższych regulacji prawnych lub chociażby formalnych wskazówek interpretacyjnych, które precyzowałyby, jak ochronę tę - zwłaszcza w pieczy instytucjonalnej - należałoby rozumieć. Po

${ }^{35}$ Trybunał Konstytucyjny w wyroku z 16 lutego 1999 r. w sprawie SK 11/98 stanął na stanowisku, że wprawdzie wolność religii jest ujmowana w normie konstytucyjnej zawartej w art. 53 bardzo szeroko i obejmuje wszelkie religie i przynależność do wszelkich związków wyznaniowych, to jednak nie obejmuje światopoglądu niefideistycznego. Podobne stanowisko zajął Naczelny Sąd Administracyjny w wyroku z 26 stycznia 1998 r. w sprawie I SA 1065/97. 
wtóre, pochodzenie religijne dziecka, wobec którego orzekana jest piecza zastępcza, raczej nie jest przedmiotem szczególnej uwagi współczesnej praktyki orzeczniczej. Aspektem tym sądy rodzinne się nie zajmują ${ }^{36}$, o ile nie muszą, a nawet wówczas, jeśli muszą (gdyż kwestia ta $\mathrm{z}$ jakiś względów zostanie zaakcentowana w sprawie), to niejednokrotnie napotykają na trudne do usunięcia problemy natury faktycznej. Taką trudnością jest np. brak deklarujących przynależność wyznaniową osób mających pełnić pieczę zastępczą wobec dziecka, gdy przynależy ono do konfesji, która w Polsce ma charakter mniejszościowy. W przypadku np. małoletniego muzułmanina znalezienie rodziny zastępczej, która praktykowałaby islam jest (poza obszarem Polski wschodniej, a głównie okolic Kruszynian i Bohoników) niewątpliwie trudne. Podobnie jak niełatwe jest znalezienie takiej placówki opiekuńczo-wychowawczej, w której problemów nie rodziłoby zachowanie wskazań szariatu. Pozostając przy wyznawcach islamu, nie sposób na marginesie nie odnotować i tego, że pomimo iż zgodnie z treścią wiążącego Polskę art. 20 Konwencji o Prawach Dziecka ustanawianie pieczy zastępczej winno następować z uwzględnieniem instytucji kafala, nie bardzo wiadomo, co $\mathrm{w}$ realiach prawa polskiego przepis ten konkretnie miałby oznaczać.

Wracając do okoliczności, które sprawiają, że analizowana ochrona pozostaje jedynie dobrze brzmiącym hasłem, które w zasadniczej mierze odbiega od rzeczywistości, należy zauważyć, że problemem jest również, jak się wydaje brak odpowiedniego zainteresowania samych Kościołów i związków wyznaniowych (głównie tzw. mniejszościowych) włączaniem się w organizowanie pieczy zastępczej, i to pomimo istniejących ku temu od lat możliwości prawnych. Jak wynika np. z danych statystycznych zawartych $\mathrm{np} . \mathrm{w}$ „Wykazie zarejestrowanych placówek opiekuńczo-wychowawczych w woj. śląskim" poza placówkami prowadzonymi przez Kościół katolicki placówek prowadzonych przez inne kościoły i związki wyznaniowe w wykazie tym nie ma ${ }^{37}$.

Na posiedzeniu Rady Unii Europejskiej 25 październiku 2019 r. przyjęto, z inicjatywy Polski, porozumienie o zmianie Rozporządzenia Rady (WE) nr 2201/ 2003 z dnia 27 listopada 2003 r. dotyczącego jurysdykcji oraz porozumienie uznawania i wykonywania orzeczeń $\mathrm{w}$ sprawach małżeńskich oraz $\mathrm{w}$ sprawach dotyczących odpowiedzialności rodzicielskiej uchylające rozporządzenie (WE)

\footnotetext{
${ }^{36} \mathrm{~W}$ tym kontekście znamienny jest fakt, że do 14 listopada $2014 \mathrm{r}$., tj. wydania przez Sąd Najwyższy w składzie siedmioosobowym uchwały w sprawie III CZP 65/15, jasno nakazującej, aby sądy opiekuńcze, orzekając umieszczenie dziecka w pieczy zastępczej, oznaczały konkretną rodzinę zastępczą lub rodzinny dom dziecka, sądy w tym zakresie przenosiły swoje uprawnienia na rzecz jednostki organizacyjnej pomocy społecznej. O tym, do jakiej rodziny trafi dane dziecko, częstokroć decydował nie sąd rodzinny, lecz starosta.

${ }^{37}$ Zob. http://www.katowice.uw.gov.pl/wdzps/ipiecza.html [dostęp: 20.01.2017].
} 
nr 1347/2000 („Bruksela II bis”) ${ }^{38}$. Zmiany wskazanego rozporządzenia - które zostaną dookreślone do 2022 r. - mają polegać na wprowadzeniu przepisu, który „zobowiązuje państwa członkowskie UE, by zachowywały prawa dziecka do tożsamości kulturowej, religijnej i językowej w postępowaniach o ustanowienie pieczy zastępczej"39. Czy zmiany te będą stanowiły realną ochronę tożsamości religijnej dziecka w pieczy zastępczej w Polsce - czas pokaże.

\section{PIŚMIENNICTWO}

AndrZeJewski Marek: Pojęcie pieczy zastępczej, [w:] System Prawa Prywatnego. Prawo rodzinne i opiekuńcze, red. Tadeusz Smyczyński, t. 12, Warszawa: Wydawnictwo C.H. Beck 2011, s. 436-449.

ANDRZEJEwSKi Marek: Sytuacja prawna wychowanka pieczy zastepczej, [w:], Status prawny osoby małoletniej - piecza zstępcza, kontakty, przysposobienie, red. Marek Andrzejewski Warszawa: Instytut Nauk Prawnych PAN 2020, s. 15-77.

BABIUCH Helena: Konstytucyjne prawa rodziców w zakresie wychowania dziecka, [w:] Realizacja $i$ ochrona konstytucyjnych wolności $i$ praw jednostki $w$ polskim porzadku prawnym, red. Mariusz Jabłoński, Wrocław: Uniwersytet Wrocławski 2014, s. 176-198.

Baranowska-Bolesta Maria: Legal Guardianship of Minors. Selected Issues, „Studia Iuridica Lublinensia" 2020, nr 1, s. 47-66.

Burtowy Michał, ZajączKowska-Burtowy Joanna: Tożsamość dziecka w pieczy zastępczej. Po 30 latach od uchwalenia Konwencji o prawach dziecka, „Prokuratura i Prawo” 2020, nr 1, s. 101-115.

DoLeCKI Henryk (red.): Kodeks rodzinny i opiekuńczy. Komentarz, Warszawa: Wolters Kluwer 2013.

GunN Jeremy: The Complexity of Religion and the Definition of „Religion” in International Law, „Harward Human Rights Journal” 2003, nr 16 s. 189-215.

HARBATSKI Andrei: Tożsamość religijna a bezpieczeństwo konfesyjne: wspótczesne wyzwania (na przykładzie Republiki Białorusi), „Pogranicze. Studia Społeczne” 2015, nr 25, s. 135-150.

HeLlinckx Walter: Nowe tendencje $w$ opiece nad dzieckiem $w$ Europie, [w:] Zmiany w systemie opieki nad dziećmi i młodzieża. Perspektywa europejska, red. Zofia Waleria Stelmaszuk, Katowice: Śląsk 2001. 2015, s. 115-134.

JAKUSZewicz Adam: Prawo rodziców do wychowania dzieci zgodnie z własnymi przekonaniami a wolność sumienia i religii dzieci w Konstytucji RP oraz w Konwencji o Prawach Dziecka, „Studia z Zakresu Prawa, Administracji, Zarządzania UKW” 2013, nr 3, s. 115-135.

KroczeK Piotr: Sytuacja prawna dzieci w kontekście Chrztu świętego $i$ wychowania religijnego, „Studia Oecumenica” 2013, nr 13, s. 161-174.

KroczeK Piotr: Wychowanie. Optyka prawa polskiego i kanonicznego, Kraków: UPJPII 2013.

KRUKOwski Józef: Polskie prawo wyznaniowe, Warszawa: LexNexis 2005.

Libiszowska-ŻóŁtkowska Maria: Prolegomena, [w:] Tożsamości religijne w spoleczeństwie polskim. Socjologiczne studium przypadków, red. Maria Libiszowska-Żółtkowska, Warszawa: Difin 2009, s. 44-63.

${ }^{38}$ Zob. https://www.gov.pl/web/sprawiedliwosc/wielki-sukces-polski-unia-europejska-bedziechronic-tozsamosc-kulturowa-dzieci [dostęp 15.10.2021].

${ }^{39}$ Tamże. 
ŁAKOMA Sylwia: Instytucja rodzin zastepczych $w$ prawie administracyjnym, Łódź: Uniwersytet Łódzki 2014.

Mielicka Halina: Tożsamość indywidualna a tożsamość spoteczna jako wymiar religijności, [w:] Tożsamości religijne $w$ społeczeństwie polskim. Socjologiczne studium przypadków, red. Maria Libiszowska-Żółtkowska, Warszawa: Difin 2009, s. 18-35.

OżóG Michał: Prawo rodziców do wychowania dziecka zgodnie z własnymi przekonaniami w świetle Konstytucji Rzeczypospolitej Polskiej z dnia 2 kwietnia 1997 r., „Studia z Prawa Wyznaniowego" 2015, nr 18, s. 263-264.

PietrzaK Michał: Prawo wyznaniowe, Warszawa: LexisNexis 2010.

SARNECKI Pawel: Uwagi do artykulu 48 Konstytucji, [w:] Konstytucja Rzeczypospolitej Polskiej. Komentarz, red. Leszek Garlicki, t. 3, Warszawa: Wydawnictwo Sejmowe 2003.

Schulz Anna: Zastrzeżenia, deklaracje, sprzeciwy do Konwencji o Prawach Dziecka, [w:] Konwencja o Prawach Dziecka. Analiza i wyktadnia, red. Tadeusz Smyczyński, Poznań: Ars Boni et Aequi 1999, s. 115-127.

SmyczyŃski Tadeusz (red.): System Prawa Prywatnego. Prawo rodzinne i opiekuńcze, t. 11. Warszawa: Wydawnictwo C.H. Beck 2014.

Stelmachowski Andrzej: Zarys teorii prawa cywilnego, Warszawa: Wydawnictwo Naukowe PWN 1998.

Świto Lucjan, Matżeństwo i rodzina wobec zagrożeń spoleczno-cywilizacyjnych. Kontekst prawny, „Biuletyn Stowarzyszenia Kanonistów Polskich” 2020 nr 33, s. 221-243.

TomkiEwicz Małgorzata: Islamska , kafala” a prawo polskie, [w:] Wolność sumienia i religii a bezpieczeństwo i porzadek publiczny, red. Jerzy Nikołajew, Paweł Sobczyk, Konrad Walczuk, Siedlce: Wydawnictwo Diecezji Siedleckiej UNITAS 2017, s. 149-174.

WARCHAŁOWSKI Krzysztof: Władza rodzicielska a wolność religijna dziecka w prawie polskim, „Annales Canonici Monographiae” 2015, nr 3, s. 199-214.

WIERCIŃSKI Jacek (red.): Kodeks rodzinny i opiekuńczy. Komentarz, Warszawa: LexisNexis 2014.

\section{TOŻSAMOŚĆ RELIGIJNA DZIECKA W PIECZY ZASTĘPCZEJ}

\section{Streszczenie}

Aspekt religijny w wychowaniu dzieci nie ogranicza się wyłącznie do edukacji rodzicielskiej, prawo do zachowania swojej tożsamości religijnej mają także same dzieci dorastające w naturalnym środowisku rodzinnym. W równym stopniu przysługuje ono jednak także dzieciom pozostającym w pieczy zastępczej. Czy jednak prawo to jest faktycznie w Polsce przestrzegane? Czy np. dwóch trzynastoletnich muzułmanów z Turcji, zatrzymanych na Dworcu Centralnym w Warszawie po nielegalnym przekroczeniu granicy, może złożyć wniosek o umieszczenie w rodzinie zastępczej lub instytucji, w której nie je się wieprzowiny, gdzie mogą pościć w miesiącu ramadan i studiować Koran? Czy katoliccy rodzice, którzy zostali pozbawieni opieki rodzicielskiej, mogą żądać, aby ich czteroletnie dziecko, które jest umieszczone w rodzinnym domu dziecka prowadzonym przez obojętne religijnie małżeństwo, uczestniczyło w cotygodniowej Mszy św. i zapoznawało się z Biblią? W niniejszym artykule podjęto próbę odpowiedzi na te pytania.

Przektad angielskiego abstraktu Stanistaw Sarek

Słowa kluczowe: religia; dziecko; piecza zastępcza; autorytet rodzicielski. 